\title{
DISTRIBUTION OF HYALURONIDASE IN THE RAM SPERMATOZOON
}

\author{
G. R. BROWN \\ A.R.C. Unit of Reproductive Physiology and Biochemistry, \\ 307 Huntingdon Road, Cambridge CB3 07Q
}

(Received 28th April 1975)

Hyaluronidase is widespread in the semen of mammals and high concentrations occur in bull and ram semen (Buruiana, 1956). It has been suggested (Stambaugh \& Buckley, 1969; Hartree, 1971) that hyaluronidase may play a role in passage of spermatozoa through the zona pellucida, e.g. by modifying the structure of this membrane to make it more susceptible to the action of acrosin which is widely believed to be involved in the penetration process (Stambaugh et al., 1969; Zaneveld et al., 1970).

If hyaluronidase and acrosin were to act co-operatively on the zona pelluci$\mathrm{da}$ it is likely that they would be similarly situated within the acrosome, and therefore the distribution of hyaluronidase in ram spermatozoa was investigated by the fractionation procedure described to study the distribution of acrosin in ram spermatozoa (Brown \& Hartree, 1974). Washed spermatozoa, which contain approximately $75 \%$ of the semen hyaluronidase (Brown, 1974), were frozen and thawed in $0.25 \mathrm{M}$-sucrose and subjected to vortex mixing. The suspension was centrifuged to give supernatant S1. The pellet was washed twice, by centrifuging, with sucrose. The first washing fluid (S2) was collected and the washed pellet of denuded spermatozoa was resuspended in sucrose. This procedure results in the removal from spermatozoa of the plasma membrane, the outer acrosomal membrane and the contents of the acrosome. The inner acrosomal membrane and the equatorial segment remain in close apposition to the nucleus (Brown et al., 1975). Hyaluronidase activity was measured by the method of Aronson \& Davidson (1967), except that release of $\mathrm{N}$-acetylglucosamine was non-linear during $15 \mathrm{~min}$, and incubation time was therefore reduced to $5 \mathrm{~min}$. Bovine serum albumin $(0.25 \mathrm{mg})$ was present in the system. The combined effects of these modifications was a 3-fold increase in apparent enzyme activity. Hyaluronic acid was prepared from human umbilical cord (Jeanloz, 1965). Experiments were carried out with seven batches of pooled ram semen and two batches of epididymal spermatozoa each from a pair of epididymides.

Between 48 and $57 \%$ of the hyaluronidase activity in washed ejaculated spermatozoa remained bound after the denudation process (Table 1). Corresponding values for washed epididymal spermatozoa were 60 and $77 \%$. The true values for bound hyaluronidase in washed ejaculated cells may be of the order of $70 \%$ of the total, because particulate and soluble hyaluronidase were found in the combined supernatants, S1 and S2. The mixed fraction contained $1.6 \mathrm{units} / \mathrm{ml}$ 
Table 1. Hyaluronidase units ( $\mu \mathrm{mol} \mathrm{N}$-acetylglucosamine released $/ \mathrm{min}$ at $37^{\circ} \mathrm{C}$ ) in fractions obtained from the disruption of ram spermatozoa

\begin{tabular}{ccccc}
\hline & $\begin{array}{c}\text { Vortex-mixed } \\
\text { suspension }\end{array}$ & $\begin{array}{c}\text { Supernatant } \\
\text { S1 }\end{array}$ & $\begin{array}{c}\text { Supernatant } \\
\text { S2 }\end{array}$ & $\begin{array}{c}\text { Denuded } \\
\text { spermatozoa }\end{array}$ \\
\hline Ejaculated spermatozoa & & & & \\
1 & 8.5 & 1.7 & 0.6 & 4.3 \\
2 & 8.3 & 2.3 & 0.9 & 4.7 \\
3 & $8 \cdot 0$ & $2 \cdot 6$ & 0.6 & 4.0 \\
4 & 7.0 & 1.3 & 0.2 & 3.6 \\
5 & $5 \cdot 3$ & 1.0 & 0.2 & 2.7 \\
6 & $7 \cdot 1$ & 1.9 & 0.3 & 4.0 \\
7 & 7.1 & 1.4 & 0.3 & 3.4 \\
Epididymal spermatozoa & & & & \\
1 & 8.9 & 1.8 & 0.4 & 6.8 \\
2 & 11.3 & 2.2 & 0.2 & 6.8 \\
\hline
\end{tabular}

Listed values are units present in a volume of fraction obtained from $3 \times 10^{9}$ spermatozoa.

of semen, but after it had been centrifuged for $2 \mathrm{hr}$ at $100,000 \mathrm{~g}$ the clear fluid contained 0.9 units. The sedimented material appeared to consist mostly of membrane fragments together with a few spermatozoa. Since only two lots of epididymal spermatozoa were examined and since the supernatants from them were not examined further it is not possible to attach significance to the higher proportion of bound hyaluronidase in epididymal spermatozoa. No further hyaluronidase activity could be extracted from either epididymal or ejaculated spermatozoa by further washing of the denuded sperm pellet.

More than half of the hyaluronidase in washed spermatozoa remained bound after the denudation treatment. It is therefore likely that at least a similar proportion of the sperm hyaluronidase, together with the acrosin, will be carried by a ram spermatozoon as it passes through the zona pellucida. Since in other animals the zona pellucida is susceptible to the action of hyaluronidase preparations (da Silva Sasso, 1959; Konecny, 1959; Fléchon, 1974) and since, in a number of animals (including cattle and sheep) the egg has normally shed both the cumulus oophorus and corona radiata before it meets the spermatozoa (Restall, 1967; McLaren, 1968; R. M. Moor, personal communication), these results add weight to the hypothesis that hyaluronidase may play a role in penetration of the zona membrane by spermatozoa.

\section{REFERENCES}

Aronson, N.N., JR \& DAvidson, E.A. (1967) Lysosomal hyaluronidase from rat liver. F. biol. Chem. 242, 437-440.

BRown, C.R. (1974) The distribution of hyaluronidase, trypsin-like protease and trypsin inhibitor in ram semen. M.Phil. thesis, Council for National Academic Awards, 344-354 Gray's Inn Road, London WCIX 8BP.

Brown, C.R. \& HARTREe, E.F. (1974) Distribution of a trypsin-like proteinase in the ram spermatozoon. J. Reprod. Fert. 36, 195-198.

Brown, C.R., ANDANI, Z. \& HARTree, E.F. (1975) Studies on ram acrosin. Isolation from spermatozoa, activation by cations and organic solvents, and influence of cations upon its reaction with inhibitors. Biochem. F. 149, 133-146.

Buruiana, L.M. (1956) Sur l'activité hyaluronidasique et trypsinique du sperme. Naturwiss. 22, 523.

DA Silva Sasso, W. (1959) Existence of hyaluronic acid at the zona pellucida of the rabbit's ovum. Acta anat. 36, 352-357. 
FLÉCHON, J.E. (1974) Application of cytochemical techniques to the study of maturation of gametes and fertilization in mammals. Multipurpose use of glycolmethacrylate embedding. Histochem. 7. 6, $65-67$.

HARTReE, E.F. (1971) Lysosomes and fertilization. In Of Microbes and Life, pp. 271-303. Eds J. Monod \& E. Borek. Columbia University Press, New York.

Jeanloz, R.W. (1965) Methods in Carbohydrate Chemistry, Vol. V, pp. 154-157. Ed. R. L. Whistler. Academic Press, New York.

Konecny, M. (1959) Etude histochimique de la zone pellucide des ovules de Chatte. C. r. Séanc. Soc. Biol. 153, 893-894.

MaLAren, A. (1968) Fertilization, cleavage and implantation. In Reproduction in Farm Animals, pp. 115133. Ed. E. S. E. Hafez. Lea \& Febiger, Philadelphia.

Restall, B.J. (1967) The biochemical and physiological relationships between the gametes and the female reproductive tract. Adv. Reprod. Physiol. 2, 181-212.

Stambaugh, R. \& Buckley, J. (1969) Identification and subcellular localization of the enzymes effecting penetration of the zona pellucida by rabbit spermatozoa. F. Reprod. Fert. 19, 423-432.

Stambaugh, R., Brackett, B.G. \& Mastroianni, L. (1969) Inhibition of in vitro fertilization of rabbit ova by trypsin inhibitors. Biol. Reprod. 1, 223-227.

Zanevel. , L.J.D., Robertson, R.T. \& Wrlliams, W.L. (1970) Synthetic enzyme inhibitors as antifertility agents. FEBS Letters 11, 345-347. 